construction of Seen | Unseen must have been a liberating exploration. If Kemp asks a lot of his readers - one should read the book straight through, if possible, to appreciate the dialogues between chapters and between characters separated by centuries - we can't begrudge him a little confusion because he invited everyone to the party he has arranged with his favourite students of nature.

"My final plea, Kemp offers, " is for profes- sionals in each 'field' to exercise generosity and tolerance... I believe that we surrender our human 'wholes' to our specialist 'parts' at our peril." Not only is this plea to academics selfevidently sensible and bound to be rewarding if heeded, it is hard today not to read it as wisdom for the wider world.

Bart Kahr is in the Department of Chemistry, University of Washington, Seattle,

Washington 98195, USA.

\title{
EXHIBITION
}

\section{Sowing the seeds}

\section{Gregor Mendel: Planting the Seeds of Genetics \\ The Field Museum, Chicago, until \\ 1April2007, then touring the US until \\ September 2008. \\ www.fieldmuseum.org/mendel}

\section{Simon Mawer}

Until now you had to travel to the Mendel Museum in Brno, Czech Republic, to see the relics of Gregor Mendel's life. But in September, the Field Museum in Chicago opened its doors to the exhibition Gregor Mendel: Planting the Seeds of Genetics. Visitors can witness at first hand the microscope Mendel used to make his ground-breaking observations - he was the first to demonstrate conclusively that only a single pollen grain is needed for fertilization - and the telescope with which he observed sunspots. Perhaps most poignant of all, they can see the spectacles through which the short-sighted friar viewed his world. Mendel has often been billed as something of a mystery man in the history of science, so, with genetics set to be the focus of much attention in the twenty-first century, it is appropriate that he should be the subject of a popular exhibition.

The exhibition isn't vast - unlike Darwin, Mendel left little behind - but it is beautifully designed and strikes an excellent balance between the more serious documentary side of the story and the kind of interactive display that is obligatory these days. Children can cross-breed virtual peas on screen, and, having followed Mendel's algebraic argument, open an oversized plastic pea pod to discover white and green peas in a perfect three-to-one ratio.

Their parents, meanwhile, can get to grips with lucid and informative captions that set Mendel's work in historical context and explain some of the issues surrounding his discoveries. For example, among a selection of books from the abbeylibrary, there is Mendel's own copy of the German edition of Darwin's On the Origin of Species, open at a page where, tantalizingly, Mendel has marked a piece of text with pencil lines in the margin and a single, enigmatic exclamation point. This is where Darwin writes: ${ }^{\alpha}$ There are many laws regulating variation,

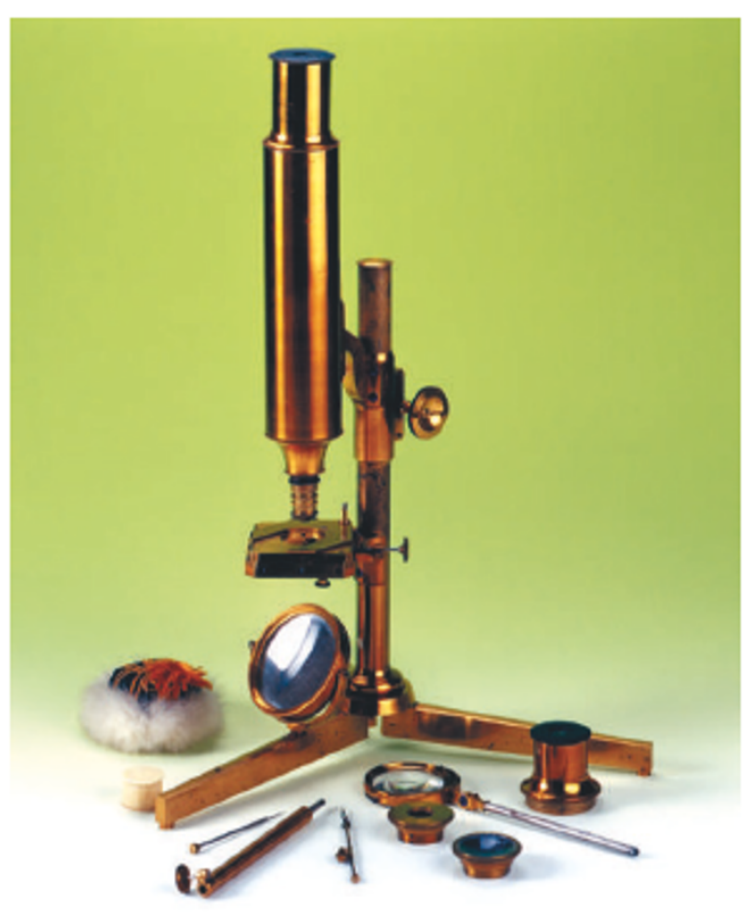

Mendel's microscope can now be seen in Chicago.

some few of which can be dimly seen." The irony is, of course, that at the very time that Darwin was writing those words, Mendel was shedding a dazzling light on those dimly seen laws. Had Darwin only read, and understood, Mendel's work, he would have found there the mechanism of inheritance that his theory of natural selection so desperately needed.

Many of the personal documents on display are facsimiles (the originals were considered too delicate to travel), but they are beautifully exact copies, and Mendel's meticulous meteorological records are original. So too is the letter from Carl von Naggeli, the botany professor with whom he corresponded and who famously failed to grasp the significance of the work done by the self-effacing friar from Brünn (as Brno was known during the Austrian empire). Appropriately, the Mendel section closes with a life-size portrait of Mendel as abbot, a promotion that effectively put an end to his research.
From Mendel we move on, with a nod in the direction of Francis Galton, to a brief consideration of genetics in the twentieth century. The Field Museum is a natural-history institution, so it is no surprise that this later part of the display has a deliberate natural-history emphasis, rather than the biomedical one that is now so often the stuff of genetics.

A further facet of this small but intriguing exhibition is a group of genetically inspired artworks. These range from a large photograph by Susan Degas of a honeycomb (Mendel bred bees), which looks uncannily like a DNA microarray, to Christine Borland's pedigree of a real family with Huntington's disease, transformed into a stunning mobile with agate disks to represent the individuals.

There is, however, a ghost at this feast of science, history and art, an item that is conspicuous by its absence: Mendel's famous 1865 paper that started it all, 'Versuche iuber Pflanzen-Hybriden'. The exhibition has an original print version on display, but what about the manuscript copy in Mendel's own immaculate copperplate? There is a facsimile of a single sheet, but where is the real thing? The answer is, I'm afraid, we don't really know. This seminal paper, the legal property of the Abbey of St Thomas in Brno, is not in the abbey's possession. Neither is it accessible to the public. Following its disappearance from a Moravian bank vault during the Second World War (when it was photographed), the manuscript resurfaced in the $1990 \mathrm{~s}$ in the possession of a member of the Mendel family in Germany. So the story goes. Quite why there should be such secrecy over this valuable artefact I do not know. I suspect it is something to do with politics. Simon Mawer lives in Rome and is the author of Mendel's Dwarf and other novels, as well as the companion book to this exhibition, Gregor Mendel: Planting the Seeds of Genetics (Abrams, 2006).

\section{Corrections}

In his review of Does Measurement Measure Up? How Numbers Reveal and Conceal the Truth by John M. Henshaw (Nature 442,357, 2006), David Colquhoun criticized the methods of ranking the quality of teaching at UK universities. In fact, the Quality Assurance Agency for Higher Education (QAA) stoppedits assessment of the teaching quality of individual subjects, resulting in a graded numerical profile, in 2001, and discourages others from using its judgements in league tables.

In a review of Reconceiving the Gene: Seymour Benzer's Adventures in Phage Genetics by Frederick Lawrence Holmes (Nature 443, 509, 2006), we omitted to mention that the book was completed and edited by William C. Summers. We apologize to Professor Summers for this oversight. 